\title{
FACTORS SUPPORTING DIGITAL MARKETING OF COMPETITIVE RATTAN PRODUCTS IN MEDAN CITY
}

\author{
Ritha F. Dalimunthe \\ Universitas Sumatera Utara \\ Medan, Indonesia \\ rithadalimunthe@gmail.com
}

\begin{abstract}
Entrepreneurs have an important role in improving the small industry of an area like Medan municipality. It can be done through the increase of the added value of raw materials into semi-finished materials or finished goods in local area and can be marketed overseas so that it can open employment and increase the income of the community and local economic improvement. The purpose of this research is to analyze the influence of model implementation through training and assistance to increase the competitiveness of rattan craftsmen. By conducting training and facilitation, the researcher hopes to get an idea of the development and improvement of competitiveness of rattan entrepreneurs whose results are the study materials in developing and increasing the competitiveness of rattan craftsmen. The research method that will be done is Experimental Design method. The sample of the research to be tested in this research is 31 rattan craftsmen. The method is purposive random sampling with the criteria of the respondents that consists the rattan craftsmen who are in Medan city. The results showed that there was an influence of training and assistance on the competitiveness of rattan craftsmen in Medan. Craftsmen as entrepreneurs have an understanding of good entrepreneurship after training and mentoring. They should have a long-term strategy in the face of competition. Competition at the global level becomes an issue that requires the craftsmen to have both short-term and long-term strategies in running the business. This research suggested the local government making policies facilitate the handling of permits and participation in marketing the products of handicrafts.
\end{abstract}

\section{Keywords—Digital Marketing; Competitiveness}

\section{INTRODUCTION}

Excavation of entrepreneurial potential to specialization in an important regional region gets attention. entrepreneurial area is certainly necessary to create a working climate in order to increase the added value of raw materials and create jobs and increase local revenue. This, of course, makes the position of entrepreneur is very important in realizing the development of regional economics and people empower [1]. Entrepreneurs need to build entrepreneur-based strategies to take risks in creating programs to achieve established vision, mission, and strategy relating to financial management, marketing, business processes, and human resources as well as establishing standard operating procedures. So through this effort, the entrepreneur can be competitive

According to [2], to achieve high competitiveness, an entrepreneur must be able to increase innovation, creative and productivity so that can compete both in product and price. Understand that in making the design should be more varied. Patented product design can obtain greater economic value. Marketing products through communities and associations of organizations so that they are recognized by members of the organization. Offer products through public figures. Keep customer satisfaction.

In addition to improving the competitiveness of an entrepreneur must be able to achieve competitive advantage through five things, namely Price or value, Customers will see products that have competitive prices and good value. Pleasing consumers, consumers really hope to get satisfactory service and good communication. A good consumer experience will make consumers tell their relatives, whereas a bad experience will also spread quickly. The need for recording, the necessity of recording of products, especially the attributes of the product.

Asean Economic Community as a form of cooperation in improving the economies of nations in ASEAN can be a threat for entrepreneurs in Indonesia and will increase the reduction of the number of entrepreneurs especially if not have the competitiveness.

To be able to survive in addition to competitiveness of entrepreneurs must also be able to master the concept of digital marketing that can help entrepreneurs introduce products to the public on a broad scale.

\section{RESEARCH METHOD}

This research is a quantitative research, quantitative method with explanatory research approach that aims to analyze the influence of 
factors that support digital marketing to business competitiveness.

\section{POPULATION AND SAMPLE}

The population and sample of this research are rattan entrepreneurs who are located in Medan city purely doing business. The number of research samples to be tested in this study is 31 businesses. The informants of this research are University of North Sumatera student, cooperative and SME service, trade office, exporters association, Indonesian Export Training Center, university.

\section{DATA ANALYSIS}

Analysis of this research data using multiple linear regression test, which analyzed the kator-factor variable supporting digital marketing to business competitiveness.

\section{RESULT}

\section{A. History of Rattan in Indonesia}

Rattan in Indonesia has a long history, its own existence has been for centuries. In ancient times rattan was regarded as a politically-economically meaningful luxury so it was often brought as a brighter for the king in the opposite country. For example, the provision of "rattan cane" in the sriwijaya period to one of the works in India, the "rattan war armor" which marks the good relationship of Majapahit-China, the "white rattan" which binds the empire to the Sumatran peninsula at the beginning of the Islam- India.

In the period of colonialism, rattan has become a commodity trading with high economic value. The proof, the Dutch who entered the kingdom of Kutai began to buy rattan by barter, especially with staples, fabrics, and others.

In detail, the history of the development of cultivation and trade of rattan is very minimal found, but the speakers who can tell about rattan is still so much and can du jppai in the village/village. In Kutai Barat for example, many Dayak ethnic uses of rattan in particular are ethnic kutai and Dayak. The community of kutai and Dayak use rattan as a binder of house building and other household appliances needs. This encourages people to grow and cultivate rattan in accordance with the types that are often used such as; rattan sega, jahap, seltup, white pulut, red pulut, and manau.

According to historical records made by K. Heyne in "De Nuttinge Platen Van Indonesia," it is mentioned that the first type of rattan cultivated in Indonesia is the type of rattan sega.Pembudidayaan done in anticipation of rattan rarity because at that time the type of rattan sega increasingly difficult sought especially not far from the edge of the village and the edge of the river. The first rattan garden that was established and automatically pioneered in rattan cultivation in Indonesia is located in a neighboring village near the town of Butok, and the area around the village Dadahup, Kapuas, both located in the province of central Kalimantan. The cultivation activities have started around 1850. In the area of plPalembang rattan cultivation began since 1905 . At that time there are many fields of shifting cultivation after harvesting more than 2-3 times become infertile so planted with rubber and plants rattan.In addition, the state forest area is still large and the population tend to be a little so many farmers open new land for rattan.

Knowledge of the benefits and utility of rattan widely makes it popular and high economic value so that it becomes one of income source for rattan producing areas especially outside Java island such as Kalimantan, Sulawesi, and Sumatera. Rattan began to be traded widely between Pulau and even between countries since 1918. Demand for rattan continues to increase and as much as possible and there is demand for new types so that the type of planting is also more and more. The high selling value of rattan and the high demand encouraged the farmers to cultivate rattan on a large scale until the 1980s. At that time the price of $1 \mathrm{~kg}$ of rattan sega worth 1 liter of gasoline or $1 \mathrm{~kg}$ of rice. The farmer experienced the packaging period at the time.Especially with the absence of commodities that can combat rattan at that time, rattan increasingly marajai market.

However, in 1987 until now the price of rattan became no longer comparable. This is the result of closing the tap of rattan exports abroad and the government's policy of exchanging rattan exports changed leadership and tended to benefit certain parties not necessarily farmers. The rattan that has experienced its golden days may not be a 'living history.

B. Description of Cooperation Partners in
Training and Development of Rattan
Craftsmen with CIKAL USU Business and
Technology Incubator Center For
Entrepreneur Strategy
CIKAL Business and Technology Incubator Center is an incubator institution under the Institute of Community Service and Devotion (LPPM) of North Sumatra University. CIKAL's Business and Technology Incubator Center is an intermediary institution conducting incubation process. Incubation activities are given in the form of coaching process, mentoring, development serte to beginner entrepreneur or Tenant.

Description of Cooperation Partners in Training and Development of Rattan Craftsman by BBPPEI For Entrepreneur Strategy

This institution is a place for entrepreneurial training of prospective exporters who do global 
business. BBPPEI as an import-export training agency under the auspices of the Ministry of Commerce is actively involved in improving the capability of human resources of business people (exporters and exporters).

BBPPEI offers a training package designed to meet the needs of exporters/entrepreneurs, which concerns the practical knowledge in the field of export and import management. This is indispensable for exporters/entrepreneurs, given the control of the ins and outs of import-export management in accordance with actual and prevailing policies, is a basic capital for exporters / business actors, in order to optimize the performance of the company and utilize every opportunity created in the era of globalization of trade the world today.

The training will enable participants to work on import-export process, especially in administrative settlement with Dinas Perindag, Customs and Excise Directorate, Banking, Transportation Service Company, Insurance and Container Terminal Unit. Participants can also understand trade contracts and are skilled in

Table 11

Education Based Analysis

\begin{tabular}{|c|c|c|}
\hline & Frequency & Percent \\
\hline SMP & 2 & 6.5 \\
\hline SMA & 24 & 77.4 \\
\hline D3 & 4 & 12.9 \\
\hline S1 & 1 & 3.2 \\
\hline Total & 31 & 100 \\
\hline
\end{tabular}

Based on the above table can be seen that, the majority of respondents who researched are high school graduates are as many as 24 respondents, D3 as many as four people respondents, junior high as two people respondents and $\mathrm{S} 1$ as much as one person. conducting pre-export activities such as business correspondence as well as calculation of export and import prices.

On this occasion also held a meeting with Mr.Prieyo Pratomo, Practicion of Indonesian Rattan Exporters Association. According to Mr.Prieyo Pratomo, which needs to be done so that rattan craftsmen can survive and can become exporters, rattan craftsmen must know the existing capacity. Broadly speaking the category of rattan products is divided into furniture and handicraft. Products that can be exported are the dominant products produced. Product design also needs to be considered in order to compete. Besides, rattan craftsmen also really need to follow the training for exporters as offered by BBPPEI.

C. Individual Characteristics of Respondents Based on the education description of respondents can be seen as follows,

Table 2.

Participatory Analysis In Training

\begin{tabular}{|c|c|c|}
\hline & Frequency & Percent \\
\hline IYA & 18 & 58.1 \\
\hline TIDAK & 13 & 41.9 \\
\hline Total & 31 & 100 \\
\hline
\end{tabular}

Based on the above table can be seen that, the majority of respondents have followed the digital marketing training that is as many as 18 respondents and do not follow as many as 13 respondents. marketing training description of respondents can be seen as follows,

Table 3

Analysis Based on Production Aspect

\begin{tabular}{|c|c|c|}
\hline & Frequency & Percent \\
\hline Kurang & 16 & 51.6 \\
\hline Cukup & 0 & 0 \\
\hline Baik & 15 & 48.4 \\
\hline Total & 31 & 100 \\
\hline
\end{tabular}

Based on the above table can be seen that the assessment of Production Aspects obtained the largest is less as much as 16 respondents, and Good as many as 15 respondents. 
Based on the workforce description of respondents can be seen as follows,

Table 4

Analysis Based on Labor Aspects

\begin{tabular}{|c|c|c|}
\hline & Frequency & Percent \\
\hline Kurang & 21 & 67.7 \\
\hline Cukup & 0 & 0 \\
\hline Baik & 10 & 32.3 \\
\hline Total & 31 & 100 \\
\hline
\end{tabular}

Based on the data above can be seen that the number of workers owned is still less qualified that 21 respondents who have good ability as much as 10 respondents.
Based on the entrepreneurial variables description of respondents can be seen as follows,

Table 5

Analysis Based on Digital Marketing Aspect

\begin{tabular}{|c|c|c|}
\hline & Frequency & Percent \\
\hline Kurang & 17 & 54.8 \\
\hline Cukup & 0 & 0 \\
\hline Baik & 14 & 45.2 \\
\hline Total & 31 & 100 \\
\hline
\end{tabular}

Based on the above table can be seen that the assessment of digital marketing aspect obtained the largest is less as much as 17 people respondents, and Good as many as 14 people respondents.

Table 6

Anova Test Results

ANOVA ${ }^{b}$

\begin{tabular}{|ll|r|r|r|r|r|}
\hline \multicolumn{2}{|l|}{ Model } & $\begin{array}{r}\text { Sum of } \\
\text { Squares }\end{array}$ & \multicolumn{1}{c|}{ df } & $\begin{array}{c}\text { Mean } \\
\text { Square }\end{array}$ & F & \multicolumn{1}{c|}{ Sig. } \\
\hline 1 & Regression & 12.13 & 4 & 3.078 & 2.124 & $.106^{\mathrm{a}}$ \\
& & & & & \\
& Residual & 37.687 & 26 & 1.450 & & \\
& Total & $5 ., 000$ & 30 & & & \\
\hline
\end{tabular}

a. Predictors: (Constant), TOTTNGAKRJA, aPAKAH ANDA PERNAH MENGIKUT PELATIHAN DIGITAL MARKETING, TOTPRO, Sekolah terakhir

b. Dependent Variable: DIGITLMARKTING

Based on the above table it can be seen that the value of Sig. from result of research analysis equal to 0106. Therefore, it can be concluded that the results of the study is not significantly influential. This can be seen from the value of 0.106 which is greater than the significance level of 0.005 .

Table 7

Influential Variables

\begin{tabular}{|c|c|c|c|c|c|}
\hline \multirow{2}{*}{\multicolumn{2}{|c|}{ Model }} & \multirow{2}{*}{$\mathrm{t}$} & \multirow{2}{*}{ Sig. } & \multicolumn{2}{|c|}{ Collinearity Statistics } \\
\hline & & & & Tolerance & VIF \\
\hline \multirow{5}{*}{1} & (Constant) & 3.530 & .002 & & \\
\hline & Sekolah terakhir & -.718 & .479 & .756 & 1.322 \\
\hline & $\begin{array}{l}\text { aPAKAH ANDA PERNAH } \\
\text { MENGIKUT PELATIHAN } \\
\text { DIGITAL MARKETING }\end{array}$ & 2.671 & .013 & .976 & 1.025 \\
\hline & TOTPRO & .077 & .940 & .887 & 1.128 \\
\hline & TOTTNGAKRJA & -.367 & .717 & .815 & 1.227 \\
\hline
\end{tabular}

The results showed that the variables of participation in training affect digital marketing.
This variable is the most influential variable compared to other variables. 
Table 8

Coefficient of Determinant

Model Summary ${ }^{\mathrm{b}}$

\begin{tabular}{|l|r|r|r|r|}
\hline $\begin{array}{l}\text { Mode } \\
1\end{array}$ & $\mathrm{R}$ & $\begin{array}{c}\mathrm{R} \\
\text { Square }\end{array}$ & $\begin{array}{l}\text { Adjusted } \\
\text { R Square }\end{array}$ & Std. Error of the Estimate \\
\hline 1 & $.496^{\mathrm{a}}$ & .246 & .130 & 1.20395 \\
\hline
\end{tabular}

Based on the table above can be seen that the value of $\mathrm{R}$ obtained by 0.496 or $49.6 \%$. Therefore, it can be concluded that the variables studied can only describe the research results of $49.6 \%$ and the remaining $51.4 \%$ can be explained by other variables that are not included in the study.

\section{DISCUSSION}

\section{A. The Effect of Entrepreneurship on} Business Competitiveness

The results showed that entrepreneurial variables owned by entrepreneurs have an effect on improving business competitiveness. The ability of entrepreneurship of respondents is good, it is formed because intense responders get a good understanding of various seminars or entrepreneurship training. So as to strengthen the ability of entrepreneurs. In addition to entrepreneurial skills in training or seminars, respondents often get new experiences that improve the quality of business that led to increased business competitiveness.

Talk about entrepreneurship according to [3] is not only innate talent, or field experience affairs. But also can be learned and taught. Someone who has talent berwirauaha can develop their talents through education and training. Those who become entrepreneurs are people who know the potential and learn to develop it to seize opportunities and organize business in realizing its ideals. Therefore, to become a successful entrepreneur is not enough to have only talent, but also has knowledge about all aspects of the business that will be occupied such as finance, production, marketing, and accounting.

Talent is a congenital trait that has encouraged a person to realize his great ideals. Their talents develop and are honed by the environment. Their dreams move dynamically following the learning process. Through the companies they manage, they train themselves to be ready to become world-class entrepreneurs. That is, to become a successful entrepreneur, in addition to talent, conducive environment conditions and opportunities to practice at the stages of a person's life that affect success later. Above, it can be concluded that an entrepreneur can be created through education. For that, subbahasan next will discuss about entrepreneurship education in various countries and strategies to create a reliable entrepreneur through education in Indonesia.

An entrepreneur is a risk taker, either a financial risk (a loss) or a mental risk (considered a failure), but the risk is taken with full calculation so that an entrepreneur can overcome obstacles to success constantly or balance the risks and rewards that will be obtained. By doing these three basic points, a person will become an entrepreneur.

The results of 31 entrepreneurs found similar properties of each entrepreneur [4]. There are three characteristics that make a successful entrepreneur, (1) see the challenge as positive and able to learn from mistakes, (2) have strong personal initiative, and (3) have perseverance and determination.

\section{B. Effect of Strategy on Business} Competitiveness

The results showed that there is a strategic influence on the competitiveness of entrepreneurs in the city of Medan. This research is in line with [5] research which proves that there are several factors that influence the entrepreneurial competitiveness in Semarang city, such factors as entrepreneurship and entrepreneurship strategy. Likewise with research conducted [6] which proves that the ability of entrepreneurship and business strategy positively affect the competitiveness of business entrepreneurs in Lampung. Adanya vision to improve product quality that begins from competition with other products requires entrepreneurs to menyimbun business strategy, plus again with the unstable market conditions make entrepreneurs have to develop other strategies in improving business. The condition is done by $41.4 \%$ of respondents. 
Strategy is an action plan that aligns organizational resources and commitment to achieve superior performance [3]. He also said that in business a business must have a competitive advantage where the business has a product or service that can be seen from the target market more both of its competitors.

Based on the results of visits to the University of Bina Nusantara turns out the components of competitive advantage in creating the competitiveness of an entrepreneur in the long term (entrepreneurship strategy) is seen from the advantages of human resource management in which contains the ability of entrepreneurship and business management skills. Then cost advantage is influenced by business scale and efficiency in production or technology.

The advantage of distribution where a business must have a distribution network with or through the development of distribution networks, and pem = ngembangan market and efficiency in production costs. Next is the product superiority that is seen from the quality of the product as well as the uniqueness of the product. Therefore, these four components of excellence are incorporated into the KKNI system (competency-based curriculum) with 144 credits in lectures.

The above is in accordance with the results of research conducted by Dalimunthe (2014) by using SWOT analysis it turns out that rattan craft in the face of competitors must increase market share through the expansion of network / distribution network. In addition, Dalimunthe's (2015) study also found that competence as a part of human resources has an effect on competitive advantage.

\section{CONCLUSIONS}

1. Majority of the respondents who studied are high school graduates that is as much as 24. Majority of respondents have attended the digital marketing training as many as 18 respondents. Production Aspect Assessment obtained the largest is less as much as 16 respondents.

2. The number of workers owned is still less qualified, ie, 21 respondents. The most popular digital marketing aspect is less than 17 respondents

3. Variable participation in training affects digital marketing. This variable is the most influential variable compared to other variables.

\section{References}

[1] Astuti Sulistya. 2013. Perkembangan Kewirausahaan di Indonesia.http://www.stieekuitas.wordpress.com/2013 /07/15/perkrmbangankewirausahaan-di-indonesia. 27 April 2015

[2] Saiman, Leonardus, 2014. Kewirausahaan: Teori, Praktik, dan Kasus-Kasus, Jakarta : Salemba Empat.

[3] Franco, Echdar. 2013. Training, Quizon City: kalayan Press Mktg Ent Inc.

[4] Hornaday, J. A., et al., 1983. Manajemen Strategis. Penerbit Salemba Empat, Jakarta.

[5]Hadriani,2010.MendalamiArtiEntrepreneurhttp://www.ciputr aentrepreneurship.com/entrepreneurship/mendalamiarti-entrepreneur

[6] Susanto. 2012. Peningkatan Daya Saing Industri Indonesia (JurnalKajian):http://www.lemhannas.go.id/portal/ima ges/stories/humas/jurnal/jurnal_internasional.pdf

[8] Hunger, J David \& Thomas L. Wheelen. 2003. Managemen Strategis. Penerbit Andi. Yogyakarta

[9] Kuncoro, Mudrajad, dan Anggito Abimanyu. 1995. Struktur dan Kinerja Industri Indonesia Dalam Era Deregulasi dan Deborikratisasi. Kelola ( Gajah Mada University Bussiness Review ). No. 10/IV/1995

[10] Mulyadi, 2014. Sosialisasi Ketentuan Jaminan Sosial (Jurnal Elektronik) diakses pada 10 September 2014; https://id.scribd.com

[11] Majalah Wirausaha \& Keuangan.2015. Jadi Entrepreneur Model "Francis Atau Belanda". Jakarta.

[12] Rangkuti, F, 2009. Analisis SWOT Teknik Membedah Kasus Bisnis, Edisi ke Enam Belas, Jakarta : Penerbit Gramedia Pustaka Umum.

[13] Tripomo, Tedjo Udan, 2005 Manajemen Strategi, Rekayasa Sains, Bandung

[14] Nawawi, H. 1997. Manajemen Sumber Daya Manusia, Gajah Mada Universitas Press. Yogyakarta,

[15] Veithzal, R,. 2004. Manajemen Sumber Daya Manusia Untuk Perusahaan, Jakarta, PT. Raja Grafindo Persada

[16] Moekijat. 1990. Evaluasi Pelatihan Dalam Rangka Meningkatkan Produktivitas Perusahaan. Penerbit Mandar Maju. Bandung,

[17] Subagyo, H. 2008. Pengaruh Peran Pendampingan Bidan Desa Terhadap Pengembangan Desa Siaga Di Kabupaten Blitar. Tesis.Program Pasca Sarjana. Universitas Sebelas Maret. Surakarta

[18] Amir, A. 2008. Pengaruh Penyuluhan Model Pendampingan Terhadap Perubahan Staus Gizi Anak Usia 6 - 24 Bulan. Tesis.Program Pasca sarjana.. Universitas Dipenogoro. Semarang

[19] Story, J., \& Barbuto, J. (2011). Global mindset: A construct clarification and framework. Journal of Leadership \& Organizational Studies, 18(3), 377-384. http://dx.doi.org/10.117/1548051811404 421.

[20] Gollwitzer, P. (2012). Action Phases and Mind-sets. Diunduh dari: http://www. psych.nyu.edu/gollwitzer/90Goll_Acti onPhasesMindSets.pdf/ tanggal 4 Juli 2014.

[21] Gupta, A., \& Govindarajan, V. (2002).Cultivating a global mindset. Academy of Management Executive Journal, 16(1), 116-126 